\title{
The Double Life of Veronique in Jordan and Hemingway-On the Autobiographic Implications in For Whom the Bell Tolls*
}

\author{
WANG Chao-fan, MENG Fan-mao \\ Linyi University, Linyi, China
}

\begin{abstract}
Ernest Hemingway is one of the greatest American novelists. His For Whom the Bell Tolls, a novel on Spanish Civil War, is generally regarded as "his most ambitious artistic endeavor and a heroic epic of the 20th century American literature". The protagonist, Jordan, is a brave, unselfish, and stressful fighter for fascist, who is the more mature epitome of Ernest Hemingway in the reality. It is an example of application of "meta-fiction". Both of their views on war change from being pessimistic to being optimistic; both Hemingway and Jordan are the heroes of "Grace under Pressure" and both of them start to care for the society and love others.
\end{abstract}

Keywords: Hemingway, Jordan, war, epitome, meta-fiction

\section{Introduction}

I was shocked and moved by For Whom the Bell Tolls, written by Ernest Hemingway, not only for the philanthropism and perseverance of Jordan during the process of bombing bridge, but also because of his unselfishness and calmness when he chose to sacrifice himself for saving his comrade-in-arms and the girl he loved in the end of the battle. Ernest Hemingway is regarded as a thoughtful and smart artist, a literary giant, an adventurer, and a stylistic genius in American history who won Nobel Prize in 1954. He was born on July 21, 1899, in Oak Park, Illinois; Ernest Miller Hemingway is the second child to Clarence Edmonds Hemingway and Grace Hall Hemingway. His birthplace, Oak Park, a suburb of Chicago, was a small town where it was permeated with the genteel and rigidly Protestant atmosphere. Oak Parkers were mostly protestant and exclusive. They centered many of their activities in their churches and tried to avoid the so-called outward corruptions. Hemingway's family conformed to the conventions of the town. They were devout Christians, assembling for family prayers daily after breakfast and attending the Church on Sundays.

His father, Clarence Edmonds Hemingway, enjoys outdoor activities very much and has a great influence on shaping Hemingway's personality. He is a physician and a great lover of hunting and fishing. It is from his father that Hemingway gets enthusiasm for guns and fishing trip that was later reflected in his novel's protagonist, such as Nick Adams in The Sun Also Rises.

\footnotetext{
* Acknowledgements: This article is sponsored by the program "The Acquisition of High School English Learners Studying English Attributive Clauses".

WANG Chao-fan, Class 3, Grade 2011, School of Foreign Languages, Linyi University.

MENG Fan-mao, professor, master, School of Foreign Languages, Linyi University.
} 
Hemingway enjoyed writing when he was in school, although his mother hoped his son to develop an interest in music. Choosing literary career is a right way for Hemingway, as his works enjoy an international reputation and affect a large number of writers in his contemporary time and the next generation. After graduation, he went to Kansas City and started his literary career as a journalist for the Kansas City Star. Associating with newspaper developed his facility in writing. When the First World War broke out, Hemingway aspired to be enlisted in the army, but he was rejected for 12 times. At length, he was enlisted and sent to Italy by Red Cross as an ambulance driver. He was wound in the war due to saving his comrade-in-arms and was rewarded a medal for his heroism. After he married with Hadley Richardson in 1921, he moved to Paris with his wife, where he worked as a foreign reporter for the Toronto Star. Introduced by Sherwood Anderson, Hemingway met Gertrude Stein in Pairs. He learnt a lot writing skills from her. In 1923, he published his first book Three Stories and Ten Poems, followed by In Our Time in 1924, a collection of short stories. The Sun Also Rise, For Whom the Bell Tolls, and The Old Man and the Sea are three successful novels which add a legendary color to Hemingway's life. It is agreed that Hemingway plays an important role in the world literature as well as in the American literature largely due to his novels. Hence his works are frequently read and commented world-wide. For Whom the Bell Tolls is such a good example.

For Whom the Bell Tolls, is a war novel on Spanish Civil War. It tells a story on Jordan bombing the bridge. Jordan, the main character of the novel, is a Spanish teacher in an American college. For his loving and enthusiasm of Spain land, he volunteers to be an explosive expert working closely with a guerilla band of courageous men behind the fascist lines. Finishing the whole action takes place in three days, 72 hours. It begins with Jordan contacting with the member of band, then he meets a Spanish girl named Maria who was captured and raped by fascists and falls in love with her. He is a romantic lover who understands Maria's love and pain. During the process of blowing up the strategically bridge, Jordan overcomes numerous difficulties and makes plans for blowing. After finishing the task which risks his life, he is ready to escape. On the road of escaping, his horse is shot and falls him down, and his legs are broken. As too injured to escape safely, he chooses to sacrifice himself to save his comrade-in-arms and the girl he loved. He is a true hero in facing death, a representative of that "Grace under pressure".

The novel ends with an epigraph. Everyone belongs to a community; none of us stand with alone. Any death of solider is not the matter of himself but the matter of the community. Jordan is no longer alone, as he has a group to work for and a girl he loves and dies for. The title emphasizes the importance on collective and fellow-feeling - the values that at the beginning encouraged Jordan to leave his home country to struggle a foreign war.

\section{A New Reflection of View on War of Hemingway in Jordan}

The novel For Whom the Bell Tolls is for Hemingway the climax of his four years' participation in the Spanish Civil War. This novel shows us a completely new view on war of Hemingway himself, which presents according to Jordan.

\section{The Change of View on War of Hemingway}

Hemingway spends most of his life in wars: the World War I, the Spanish Civil War, and the World War II, some of his works are also associated with war as well, from which we can understand his view on war better. 
When the World War I broke out, Hemingway was just 14. He just left school and knew nothing about life or war. In April 1916, the Unite States declared to the Germany. Filling with excitement and patriotism, he was willing to join the army. However, he failed for his poor vision. At length, he was enlisted by Red Cross as an ambulance driver. At that time, he felt proud of being a solider and aspired to become a hero and get an honor. Once in a battle, he was seriously wounded by a bomb but still stuck to saving his comrade-in-arms. After a few months' treatment, he was totally healed. In a letter to his parents, he said to his mother that she should be proud and happy of having a brave and patriotic son. When he was back to his country, he was named "national hero" by his villagers. But he was unaware that he was just a victim of the war.

After the World War I, Hemingway disillusioned from the war for he saw the flood and body fragment brought by war. He did nothing but drank. Hemingway drank gin, whiskey, vodka, and red wine several times in a day. The biography of him by Kenneth Lynn deals very squarely with his drinking problem. In his letter to F. Scott Fitzgerald in 1925, he pictured a heaven where people drank themselves to death: "I wonder what your idea of heaven would be - a beautiful vacuum filled with wealthy monogamists. All powerful and members of the best families all drinking themselves to death".

At that time, he was empty both physically and mentally. He was unable to forget the past and to plan the future. He was always alone and lonely. Just as A Farewell to Arms, one of his renowned works, Henry disillusioned from war and determined to escape to Switzerland with Catherine, the woman he most loved, to pursue a peaceful life. Facing the war, Henry chose to escape, which would also be Hemingway's choice if he were. After he experienced the First World War, his view on war completely changed, from filling with illusion to disillusion, from enthusiasm to hate.

The Spanish Civil War was the second war Hemingway experienced. His view on war had a great change through it. He bravely faced the war and transited from hate to support because the Spanish Civil War was a war for fair and he loved Spain land. It is the most important event in which the Spanish people fight with the fascists. Hemingway volunteers to Spain to be a journalist, instead, he is more like a soldier. He leads a movie during the war named The Spanish Land which disseminates the anti-fascists war. Hemingway in this time is a more mature person, but he becomes more optimistic before on the war. While his novel For Whom the Bell Tolls just describes his change according to Jordan.

\section{The Reflection in Jordan}

Hemingway writes For Whom the Bell Tolls on his own experience on Spanish Civil War. The protagonist Jordan is an American teacher, who chooses to travel across the ocean to get into the war. In the beginning of the book, Jordan already realizes the difficulty and unusual danger of his task. Bridge is going to be bombed at a precise time, but Jordan is not told the precise time. He only knows he must bomb it after the attack has started and without the cover of darkness of the night. In a dangerous profession, like a bomber, all those elements lead to additional danger. However, when his supervisor, Golz says, “... if you do not want to undertake it (the task), say so now. If you think you can not do it, say so now". ${ }^{2}$ Jordan rather willingly takes the task although he does not like it very much. With full knowledge of the danger the task involves and as an American volunteer fighting for

\footnotetext{
1 See https://en.wikiquote.org/wiki/Ernest_Hemingway.

${ }^{2}$ See http://www.jxteacher.com/fuyaping/column55147/14e64fce-68f9-4d4c-8b05-69c076a6d8bd.html.
} 
the anti-fascist cause in Spain, Jordan's courage is very impressive. Yet in this mission where he cannot see a chance of victory, he carries on. Jordan is no longer feared of failure and death; instead, he totally forgets that.

There is also a detail story happening during the process of blowing up the bridge which shows Jordan's optimism and persistence. Pablo is a gallant and hopeful anti-fascist, but now he has becomes a coper. More seriously, he disproves to bomb the bridge for avoiding risk. In order to stop Jordan from successfully finishing the task, he steals all of the explosives. Without that, Jordan could do nothing. However, Jordan does not give up his hope and finally extorts and touches Pablo. Then, they continue to proceed next step together.

Hemingway uses his experience of Spanish Civil War as the background of For Whom the Bell Tolls and expresses his optimistic and hopeful ideas on the war through Jordan. Before the Spanish Civil War, Hemingway hates war because it causes blood and disaster, which makes people suffer torment. He chooses to escape the war not bravely face it. Hemingway in that time is still not so mature in the matter of war. After involving in the Spanish Civil War, he changes his view. He thinks that people ought to fight for their legitimate right. Jordan represents Hemingway who has own a mature view on war after experiencing the Spanish Civil War. Hemingway expresses his thought that people should be against the unfair war and fight for peace and victory. The two, on the end, reach an agreement on the war. They finally choose to face the war persistently and bravely.

\section{Hemingway and Jordan: Heroes of "Grace Under Pressure"}

“Grace Under Pressure" is Hemingway's code hero who is a man's man. People see Hemingway's code hero a man of action rather than a man of words. He never talks a lot; he drinks too much and for a long time; he moves from one love affair to another; he enjoys bullfights, wild game hunting, and many other so-called manly activities. Hemingway's code hero typically suffers from some sort of wound, physically or mentally. The wound would cause him enormous pain. But he bears it with courage and dignity without complaining about it openly. The wound could be considered a kind of test, while the endurance shown in face of suffering is the most important trait of code hero.

\section{Heroic Behavior of Hemingway}

Hemingway is a real code hero in the reality.

On July 8, 1918, while distributing food and water to soldiers on the front, Hemingway was seriously injured by fragments from a Germany mortar shell, which landed just a few feet away from Hemingway. One Italian soldier standing beside him was killed instantly and another was blown off both legs. Hemingway was knocked unconsciously. When he regained his consciousness, he helped carry one seriously wounded soldier back to the first aid station. Later he described his experience in a letter to his father:

The 227 wounds I got from the trench mortar didn't hurt a bit at the time, only my feet felt like I had rubber boots full of water on hot water. And my kneecap was acting queer. The gun bullet just felt like a sharp smack on my leg with an icy snowball. However it spilled me. But I got up again and got my wounded into the dug out. I kind of collapsed at the dug out. The Italian I had with me had bled all over my coat and my pants look like somebody had made currant jelly in them and then punched holes to let the pulp out... We took off my trousers and the old limbs were still there but gee they were a load with both knees shot through and my right shoe punctured in two big places. Also over 200 flesh wounds. ${ }^{3}$

\footnotetext{
${ }^{3}$ See https://en.wikiquote.org/wiki/Ernest_Hemingway.
} 
Because of his brave behavior, he was awarded the Italian Silver Medal for Valor by the Italian government. Hemingway has tested his courage in the war and has got so close to death.

He never stops suffering from wounding during his life. His eyesight was poor when he was young, later his left eye was poked by his son and became poorer than before, but he never stopped writing and creating; he once suffered a serious car accident and was diagnosed with cerebral concussion, sometimes his mind appeared some strange images and scenes, but he continued to explore new things in life; he wounded seriously in Spanish Civil War, and worried that he could not report the development of the war to the world timely, but he still stuck to writing about the war. Amidst enormous pain, he gradually learnt to be courageous, to endure in silence, not letting emotions show, which contributed greatly to the formation of his unique style.

\section{Jordan: The First Real Hero in the Fiction of Hemingway}

Much has been written about Hemingway's heroes, but plenty of that criticism is mistaking. In fact the word hero is misleading. Nick Adams is maybe a hero, an initiate still in his early period of learning about fear. Jake Barnes in The Sun Also Rises is a tragic victim, the inside. Frederic Henry in A Farewell to Arms is a deserter and a tragic outsider. Harry in The Snow of Kilimanjaro hates himself for not being a hero, for having given in to easy money. Francis Macomber is only a kind of hero for an instant, and then he becomes a tragic victim. "The first real hero in Hemingway's fiction-someone who sacrifices himself (all the way, if necessary) for something larger (the cause), or for someone else (Maria and the band is Robert Jordan)" (SU, 2006, p. 78).

Jordan comes to Spain to fight against fascism with a mood of gay, one part of perseverance, which is also a characteristic of "Grace Under Pressure". When Jordan first sees Pablo, he dislikes him for he always behaves sadly and pessimistically. Pablo is against Jordan to blow up the bridge as he has enough of the war and wants to stay quietly in the hill.

I am tired of being hunted. Here we are all right. Now if you blow a bridge here, we will be hunted. If they know we are here and hunt for us with planes, they will find us. If they send Moors to hunt us out, they will find us and we must go. I am tired of all this. "You hear?" "What rights have you, a foreigner, to come to me and tell me what I must do?".

And he steals the equipment of blowing up the bridge. Jordan does not abandon his mission even without that equipment. He tries his best to prepare possible assault. After Pablo escapes away from the band, Jordan has to adjust his plan and organizes all the members of the band to fight for the blowing mission. Then Jordan has gained the respect and insistence in the entire band. His leading status is founded completely. He always faces difficulties with mood of gay and never gives up.

Hemingway himself is a man's man in the reality who loves hunting and bullfight which is the man's activities. He suffers numerous disasters but still believes he can create a better future. His life experience is a legend for the world and American. The most important is that he always holds out a hope in the mind and deals with problems with an optimistic attitude. That is why he becomes the greatest novelist in his time and has a profound influence on the next generation. Jordan in For Whom the Bell Tolls is the epitome of Hemingway in the reality. Jordan, like Hemingway, has an optimistic attitude when suffering difficulties and has a strong sense of responsibility for his duty. In the end of the battle, Jordan sacrifices himself to save the people he loves. Both of them are the heroes of "Grace Under Pressure", who are gallant, positive, hopeful, and responsible.

\footnotetext{
${ }^{4}$ See http://www.jxteacher.com/fuyaping/column55147/14e64fce-68f9-4d4c-8b05-69c076a6d8bd.html.
} 


\section{The Philanthropism of Hemingway and Jordan}

Both Hemingway and Jordan are great people who become more concerned with the society. They were no longer concerned with themselves, but helped other people in other hemisphere to go through the difficulties.

\section{The Change From "Small Self” to “Great Self” of Hemingway}

Hemingway lives in a turmoil period when the war constantly occurred. He experiences three wars in total. Before Spanish Civil War, he emphasizes mostly on his family, his literary creation, and the enjoyment of colorful life. He does everything with freedom such as traveling, fishing, hunting, and seeing the bullfight. He lives in a circle of himself. He seems happy in his own world and never cares for the society, that is to say, he is a person who only concerns "small self”.

However, he totally changed when the Spanish Civil War erupted. Volunteered to Spain land, he personally understands the blood and disasters brought by the war. He knows that people only hope to have a peaceful world and live a happy life. So he begins to focus on the world and the people for he loves Spain land as well as the culture. Before the Spanish Civil War erupted, in his spare time, Hemingway often goes to Spain to see the bullfight and make many friends with Spanish. Volunteered to Spain to be a reporter, Hemingway timely delivers clear and accurate information on anti-fascism war to America. He is a brave soldier more than a reporter in the battle. As for him, anti-fascism is a fair war and he devotes himself to the war and to the Spanish. And during the four years of Spanish Civil War, he leads a movie named The Spain Land. All the frames and scenes are from the real war. Due to experiencing the war personally, Hemingway dubs for the movie which sounds full of passion and indignation. When back to America, he and his mates disseminate the movie to expose the devil of fascism, hoping that people in all over the world hand in hand to fight against fascism. Even President Roosevelt invited him to White House to deliver a exciting speech on anti-fascism and gave him a highly praise. During World War II, Hemingway and his wife came to China to learn about the war situation. China is the most important army force to fight against the fascism of the eastern field. The couple visit Chiang Kai-shek and ZHOU En-lai, which enhances the communication between the Western and the Eastern.

Hemingway at this time learns to love others and show his philanthropism to the world. He does not any longer emphasize himself, but changes from "small self" to "great self", that is to say, he pays more attention to concern the world. It is a huge change for Hemingway. After experiencing the Spanish Civil War, he deeply understands the pain of people brought by the war and people's desire for peace. He feels himself so small, just one drop of water of the whole ocean in the earth. Living in this big world, he realizes the people in all the nation are the most important. They are the whole ocean; only living with them together can he achieve his value and have more force and courage to fight fascists.

\section{Jordan: An Unselfish and Sacred Image of "Great Self”}

Jordan is an unselfish hero, with confidence and noble ideas. He believes in the people and their right to govern themselves. He connects himself with the cause of the whole mankind.

Robert Jordan, as a Spanish instructor in an American university, loves Spanish land as well as its culture. He believes in liberty, equality, fraternity, and the pursuit of happiness. But to achieve it seems to be impossible under a fascistic regime. When the Spanish Civil War erupts, he leaves his job to volunteer for the Republican side. "He fought now in this war because it had started in a country that he loved and he believed in the Republic 
and that if it were destroyed life would be unbearable for all those people who believed in it". So he chooses to fight for "the government by the people" and whole-heartedly devotes to what he does. He believes the people should have right to govern themselves. Accordingly, he decides to leave his homeland to fight against the Fascism, which means he joins the Republican side in Spain. Obviously, Jordan's choice is due to the love to human beings. He wishes to take the fire-seed of freedom and happiness of human beings to fight against evil and suffering in the world, just like the ancient Greek hero Prometheus. For the benefit of the human being, he devotes himself to the just cause completely.

It would give you a part something that you could believe in wholly and totally and in which you felt an obvious brotherhood with the others who were engaged in it. It was something that you hardly known before but you had experienced now and you such importance to it and the reason for it that your own death seemed completely unimportant; only a thing to be avoided as it would interfere with the performance of your duty But the best thing was that there was something you could do about this feeling and this necessity too. You could fight. ${ }^{6}$

Jordan, when fighting with his comrade-in-arms, feels like an absolute brotherhood. He has already enjoyed it and thought his own death completely unimportant.

During the preparation for blowing the bridge, he becomes to realize it would bring bad things even death to the people he loves and he resents the order he has to do. He does not worry about himself but he would not like to hurt others. He is filled with trouble. In the end, he chooses to sacrifice himself to save the people he loves.

When in the end of the battle, Jordan's horse is heavily shot and he falls down. He knows that he could not escape safely and choose to sacrifice himself to save the people he loved. At last, Jordan persuades Maria as well as others retreating and keeps one machine gun to snipe the coming enemies by himself. When his pain grows, he thinks about committing suicide. He then decides that he must live, so that he can stall the soldiers and give the others more time to escape. Jordan is the real hero.

Jordan and Hemingway are great heroes. They are no longer only emphasizes on themselves, but start to care for the whole society. The "great self" is shown through them. Philanthropism is a respectable virtue for them, and both of them have applied to the society.

\section{Conclusion}

The life of Ernest Hemingway is an American legend. His attitude to life, his styles, and his particular types of hero in works have been recognized throughout the world. Because both his own life and his character declare a spirit of "Grace Under Pressure", which is enriched further with the development of Hemingway's thoughts.

For Whom the Bell Tolls is regarded as "his most ambitious artistic endeavor and a heroic epic of the 20th century American literature". The protagonist Jordan is the model of Hemingway's "tough guy" who is brave, persistent, philanthropic, and fair. He suffers from numerous difficulties but never loses the hope of new life; he faces death with fearless; he loves freedom very much. Jordan is the epitome of a more mature Hemingway in the reality.

Meta-fiction is a kind of writing style which connects writer's life experience with the novel's character but has more space in imaging. Take For Whom the Bell Tolls as an example, Hemingway experiences the Spanish

\footnotetext{
${ }^{5}$ See http://www.jxteacher.com/fuyaping/column55147/14e64fce-68f9-4d4c-8b05-69c076a6d8bd.html.

${ }^{6}$ See http://www.jxteacher.com/fuyaping/column55147/14e64fce-68f9-4d4c-8b05-69c076a6d8bd.html.
} 
Civil War and falls in love with a woman who becomes his third wife; what is more, he starts to come out from his circle of life turning to the society. For Whom the Bell Tolls' background is based on the Spanish Civil War, too. The protagonist Jordan falls in love with a woman Maria, and he is gallant, fair, and pays much attention on the people. The novel, For Whom the Bell Tolls, is a typical example of application of meta-fiction. Jordan is the epitome of Hemingway in the reality, who also witnesses Hemingway's growth.

\section{References}

Baker, C. (1981a). Letter to F. Scott Fitzgerald. In Ernest Hemingway: Selected letters 1917-1961. Retrieved from https://en.wikiquote.org/wiki/Ernest_Hemingway

Baker, C. (1981b). Letter to his family. In Ernest Hemingway: Selected letters 1917-1961. Retrieved from https://en.wikiquote.org/wiki/Ernest_Hemingway

Hemingway, E. (1923). Three stories and ten poems. Retrieved from https://en.wikisource.org/wiki/Three_Stories_and_Ten_Poems

Hemingway, E. (1925). In our time. Retrieved from http://www.goodreads.com/book/show/13545667-in-our-time

Hemingway, E. (1926). The sun also rises. Retrieved from http://www.goodreads.com/book/show/3876.The_Sun_Also_Rises

Hemingway, E. (1929). A farewell to arms. Retrieved from http://www.txt66.net/read2.asp?id=14799

Hemingway, E. (1940). For whom the bell tolls. Retrieved from http://www.jxteacher.com/fuyaping/column55147/14e64fce-68f9-4d4c-8b05-69c076a6d8bd.html

Hemingway, E. (1952). The old man and the sea. Retrieved from http://www.xieguofang.cn/Multilingual\%20Corpus/Hemingway\%20Ernest/Old\%20Man\%20and\%20the\%20Sea_En_Ch.htm SU, S. Q. (2006). Multi-faceted analysis of Robert Jordan in For Whom the Bell Tolls. Changjiang Literature \& Art, 5 , 75-79. 